\title{
Association between Gly241Arg ICAM-1 gene polymorphism and serum sICAM-1 concentration in the Stanislas cohort
}

\author{
Anne Ponthieux ${ }^{1,2}$, Daniel Lambert ${ }^{1,2}$, Bernard Herbeth ${ }^{1,2}$, Suzanne Droesch ${ }^{1,2}$, \\ Michèle Pfister ${ }^{1,2}$ and Sophie Visvikis* ${ }^{* 1,2}$
}

\begin{abstract}
${ }^{1}$ INSERM U 525, 30 rue Lionnois, 54000 Nancy, France; ${ }^{2}$ Centre de Médecine Préventive, 2 rue du Doyen Jacques Parisot, 54500 Vandoeuvre-lès-Nancy, France
\end{abstract}

Intracellular adhesion molecule-1 (ICAM-1), a cellular adhesion molecule that mediates the interaction of activated endothelial cells with leukocytes, is involved in various inflammatory and cardiovascular disorders. The relation between these markers and genetic polymorphism, however, remains to be elucidated. The aim of this study is to estimate the effect of a single-base polymorphism at codon 241 in exon 4 of ICAM-1 gene on serum sICAM-1 concentration in a healthy population, taking into account other biological determinants of sICAM-1 level. Serum sICAM-1 levels and the G/R241 polymorphism of the ICAM-1 gene were measured in a large healthy population consisting of 413 children aged 6-21 years and 363 adults aged 38-55 years extracted from the Stanislas cohort. The R241 allele was significantly associated with lower sICAM-1 levels and explained 3.4 and $1.9 \%$ of the sICAM-1 variability in children and adults, respectively. A codominant pattern contributed better to the model after adjustment for covariates as the RR homozygote effect was higher than that of the GR heterozygote. Moreover, significant independent associations were found between sICAM-1 and smoking, insulin resistance index (HOMA IR), interleukin-6 level, and alkaline phosphatase and aspartate aminotransferase activities. In conclusion, this study revealed a significant association between the G/R241 ICAM-1 polymorphism and serum sICAM-1 levels, probably due to the impairment in binding of ICAM-1 to leukocyte integrin Mac-1 protein. European Journal of Human Genetics (2003) 11, 679-686. doi:10.1038/sj.ejhg.5201033

Keywords: ICAM-1; polymorphism; healthy population

\section{Introduction}

The intercellular adhesion molecule-1 (ICAM-1) is expressed on vascular endothelium and plays a key role in the trans-endothelial migration of leukocytes. ${ }^{1}$ ICAM-1 is a cell-surface glycoprotein that belongs to the immunoglobulin superfamily and functions as a ligand for $\beta 2$ integrin molecules (LFA-1 and Mac-1) present on leukocytes. ${ }^{1}$

The circulating soluble ICAM-1 (sICAM-1) molecule results from a proteolytic cleavage of the membrane-bound

${ }^{*}$ Correspondence: Dr S Visvikis, Unité INSERM U525, 30 rue Lionnois, 54 000 Nancy, France. Tel: + 3303836821 84; Fax: + 3303833213 22; E-mail: Sophie.visvikis@cmp.u-nancy.fr

Received 28 August 2002; revised 3 April 2003; accepted 9 April 2003 protein and thus reflects ICAM-1 expression on endothelium. ${ }^{2}$ sICAM-1 can be measured in the serum of healthy subjects ${ }^{3}$ and its level is increased in numerous diseases such as inflammatory and auto-immune disorders, ${ }^{4}$ infections, ${ }^{5}$ graft rejections, ${ }^{6}$ cancer $^{7}$ and cardiovascular diseases. $^{8}$

The human ICAM-1 gene is located on chromosome 19p13.3-p13.2, and a single-base polymorphism in codon 241 with amino-acid substitution has been described. ${ }^{9}$ This polymorphic site G/R241 in exon 4 (also known as G/R214 if the signal peptide is not included in the codon numbering) occurs in the third immunoglobulin domain $^{9,10}$ and has been shown to be of importance in binding to leukocyte integrin Mac- $1 .{ }^{10}$ However, the exact 
functional relevance of this mutation remains incompletely understood.

The G/R241 polymorphism has been shown to be associated with ulcerative colitis, ${ }^{11}$ Crohn's disease, ${ }^{12}$ rheumatoid arthritis, ${ }^{13}$ polymyalgia rheumatica/giant cell arteritis ${ }^{14}$ and Behçet's disease. ${ }^{15}$ However, other studies failed to find a significant contribution in inflammatory diseases ${ }^{16-24}$ or atherosclerosis. ${ }^{25}$ Despite the fact that all the concerned diseases are characterized by higher levels of inflammatory markers including sICAM- $1,{ }^{4,8,26}$ there is still no study of the association between this mutation and the protein level in serum.

The aim of the present study is to estimate the association between the G/R241 polymorphism and serum sICAM-1 levels in a healthy population, taking into account the other biological determinants. In addition, potential interactions between the G/R241 polymorphism and age, sex and smoking status were tested.

\section{Methods and materials Subjects}

The sample population included 182 families with various patterns including one or two parents and at least one child. The subjects -212 boys and 201 girls aged 6-21 years, and 182 men and 181 women aged 38-55 years were drawn from the Stanislas cohort, a longitudinal family study recruited in $1994-1995,{ }^{27}$ where participants were of French origin and came from the Vosges and the south of Meurthe et Moselle (eastern region of France). Each subject gave a written informed consent to participate in the study, approved by the Local Ethics Committee of Nancy, France. This population came back for a second visit in 1999-2000. For this specific study, the subjects were selected with the following criteria: to be present at the first (1994-1995) and the second (1999-2000) health screening, free from serious and/or chronic diseases, especially cardiovascular, hepatic or renal failure; without treatment with lipid-lowering drugs. The next laboratory tests had the highest cut-off values that follow: aspartate aminotransferase (AST) or alanine aminotransferase (ALT) activities higher than $200 \mathrm{U} / \mathrm{l}$; apoE concentration, $200 \mathrm{mg} / \mathrm{l}$; orosomucoid or haptoglobulin, $3 \mathrm{~g} / \mathrm{l}$; cholesterol or triglyceride, $10 \mathrm{mmol} / \mathrm{l}$; C-reactive protein (CRP), $30 \mathrm{mg} / \mathrm{l}$; or glucose, $8 \mathrm{mmol} / \mathrm{l}$.

\section{Blood sample and data collection}

Venous blood samples were collected by venipuncture after an overnight fasting following the procedures described elsewhere. ${ }^{27}$ Data collection included the measurements of basic blood constituents, functional tests, physical examination, questionnaires on lifestyle description and medical history. Medications, notably lipid-lowering and antihypertensive drugs, oral contraceptives and hormonal replacement therapies were assessed by interview with the patient during the blood sampling. Information on alcohol and tobacco consumption was collected by self-administered questionnaires. Body-mass index (BMI) was calculated according to Quetelet's formula: weight $(\mathrm{kg}) /$ (height $^{2}$ $\left(\mathrm{m}^{2}\right)$ ). Blood pressure was calculated as the mean of three measurements taken under standardized conditions in a supine position with a sphygmomanometer.

Serum concentrations of glucose, total cholesterol, triglycerides, and activities of AST and alkaline phosphatase (ALP) were measured with commercially available kits (all from Merck, Darmstadt, Germany) on an AU5021 apparatus. Serum apoAI, apoB, and CRP were measured by immunonephelometry on a Behring Nephelometer Analyser (BN II, Dade-Behring, Marburg, Germany) with Behring reagents (Reuil-Malmaison, France). Insulin was tested by a Microparticular Enzymatic ImmunoAssay (MEIA) on an IMx device with Abbott reagents. The insulin sensitivity was estimated by the HOMA index (homeostasis model assessment index) as HOMA $=($ fasting insulin $(\mathrm{mIU} / \mathrm{l}) \times$ fasting glucose $(\mathrm{mmol} / \mathrm{l})) / 22.5$. Circulating levels of sICAM-1, interleukin-6 (Il-6) and tumor necrosis factor- $\alpha$ $(\mathrm{TNF}-\alpha)$ were measured with the commercially available enzyme-linked immunosorbent assays (R\&D System, Abingdon, UK).

\section{Genotyping}

Genomic DNA was extracted by the salting-out method. ${ }^{28}$ ICAM-1 genotyping was performed using a prototypic multilocus genotyping assay focused on cardiovascular diseases essentially as in Cheng et al. ${ }^{29}$ Briefly, each sample is amplified by a 33 cycle $^{5}$ polymerase chain reaction ( $25 \mathrm{ng}$ of genomic DNA). One of the biotinylated primer pairs in the Multiplex was designed to amplify the gene of ICAM-1. PCR product was then hybridized to oligonucleotide probes that have been immobilized in a linear array on a backed nylon membrane strip. The colorimetric detection is based on streptavidin-horseradish peroxidase conjugate and substrates.

\section{Statistical analysis}

Statistical analyses were performed with the SAS software version 8.01 (SAS Institute Inc., USA). As the distribution of serum concentrations of triglycerides, CRP, Il- 6 , TNF- $\alpha$ and sICAM-1, activities of AST and ALP and HOMA index were skewed, $\log _{10}$-transformations of these values were applied for setting purpose. Agreement of the genotype frequencies with the Hardy-Weinberg equilibrium was tested by using a $\chi^{2}$ goodness-of-fit test.

ANOVA and pairwise comparison procedure with Bonferroni correction were performed to test differences in the sICAM-1 level between age and sex groups.

Stepwise multiple regression analysis was used to test relations between sICAM-1 level and ICAM-1 gene polymorphism accounting for age, sex and the other potential covariates listed in Table 1. Analysis was carried out 
Table 1 Characteristics of population under study ${ }^{a}$

\begin{tabular}{|c|c|c|c|c|}
\hline & \multicolumn{2}{|c|}{ Children } & \multicolumn{2}{|c|}{ Adults } \\
\hline & $\begin{array}{c}\text { Boys } \\
n=212\end{array}$ & $\begin{array}{c}\text { Girls } \\
n=201\end{array}$ & $\begin{array}{c}\text { Men } \\
n=182\end{array}$ & $\begin{array}{l}\text { Women } \\
n=181\end{array}$ \\
\hline Age (years) & $15.4 \pm 3.3$ & $15.4 \pm 3.0$ & $44.7 \pm 3.9$ & $43.1 \pm 4.1$ \\
\hline $\mathrm{BMI}\left(\mathrm{kg} / \mathrm{m}^{2}\right)$ & $20.3 \pm 3.3$ & $20.4 \pm 3.1$ & $25.5 \pm 3.2$ & $24.1 \pm 4.1$ \\
\hline Systolic blood pressure $(\mathrm{mmHg})$ & $119.3 \pm 11.6$ & $114.3 \pm 9.7$ & $125.1 \pm \overline{1} 1.4$ & $120.8 \pm 14.2$ \\
\hline Diastolic blood pressure $(\mathrm{mmHg})$ & $61.3 \pm 10.6$ & $60.6 \pm 10.8$ & $75.8 \pm 8.6$ & $71.4 \pm 10.1$ \\
\hline \multicolumn{5}{|l|}{ Alcohol drinkers (g/day (\%)) } \\
\hline $\begin{array}{l}<33 \\
\geqslant 33\end{array}$ & $\begin{array}{l}16.0 \\
0.5\end{array}$ & $\begin{array}{l}12.4 \\
0.0\end{array}$ & $\begin{array}{l}52.7 \\
24.7\end{array}$ & $\begin{array}{c}40.3 \\
6.1\end{array}$ \\
\hline Alcohol in drinkers (g/day) & $7.6 \pm 6.6$ & $5.4 \pm 3.4$ & $26.6 \pm 24.8$ & $13.5 \pm 13.6$ \\
\hline \multicolumn{5}{|l|}{ Current smokers (cig/day (\%)) } \\
\hline$\leqslant 10$ & 12.3 & 8.9 & 12.6 & 12.7 \\
\hline$>10$ & 5.2 & 2.5 & 15.9 & 4.9 \\
\hline Tobacco in smokers (cig/day) & $9.7 \pm 6.5$ & $10.0 \pm 5.6$ & $15.9 \pm 10.7$ & $11.9 \pm 9.8$ \\
\hline Anti-inflammatory drug use (\%) & $0.5^{-2.0}$ & 4.0 & 7.1 & 5.0 \\
\hline Oral contraceptive use (\%) & - & 19.9 & - & 19.9 \\
\hline Estrogen/progestagen use (\%) & - & 1.0 & - & 18.2 \\
\hline Menopause status (\%) & - & - & - & 1.6 \\
\hline Leukocyte count $\left(10^{9} / \mathrm{I}\right)$ & $6.51 \pm 1.48$ & $6.88 \pm 1.57$ & $6.64 \pm 1.74$ & $6.88 \pm 1.65$ \\
\hline Platelet count $\left(10^{9} / \mathrm{I}\right)$ & $241 \pm 50$ & $25 \overline{7} \pm 53$ & $240 \pm 53$ & $248 \pm 56$ \\
\hline \multirow[t]{2}{*}{ Triglycerides $(\mathrm{mmol} / \mathrm{l})^{\mathrm{b}}$} & $0.87 \pm 0.41$ & $0.93 \pm 0.52$ & $1.41 \pm 0.78$ & $1.04 \pm 0.57$ \\
\hline & $\begin{array}{c}0.7 \overline{9}^{\mathrm{c}} \\
(0.51-1.22)^{\mathrm{d}}\end{array}$ & $\begin{array}{c}0.83 \\
(0.53-1.30)\end{array}$ & $\begin{array}{c}1.24 \\
(0.73-2.10)\end{array}$ & $\begin{array}{c}0 . \overline{93} \\
(0.60-1.46)\end{array}$ \\
\hline Total cholesterol $(\mathrm{mmol} / \mathrm{l})$ & $4.30 \pm 0.72$ & $4.66 \pm 0.89$ & $5.86 \pm 0.99$ & $5.61 \pm 0.89$ \\
\hline ApoAl $(g / l)$ & $1.42 \pm 0.20$ & $1.52 \pm 0.25$ & $1.56 \pm 0.23$ & $1.71 \pm 0.27$ \\
\hline Аров $(\mathrm{g} / \mathrm{l})$ & $0.70 \pm 0.17$ & $0.78 \pm 0.21$ & $1.08 \pm 0.24$ & $0.96 \pm 0.21$ \\
\hline Glucose $(\mathrm{mmol} / \mathrm{l})$ & $4.76 \pm 0.48$ & $4.67 \pm 0.42$ & $5.10 \pm 0.53$ & $4.82 \pm 0.47$ \\
\hline Insulin $(\mu \mathrm{U} / \mathrm{ml})$ & $7.83 \pm 4.95$ & $9.52 \pm 5.94$ & $5.96 \pm 5.98$ & $6.11 \pm 4.84$ \\
\hline \multirow[t]{2}{*}{ HOMA IR (mmol/l) $)^{\mathrm{b}, \mathrm{e}}$} & $1.67 \pm 1.11$ & $2.01 \pm 1.34$ & $1.38 \pm 1.51$ & $1.38 \pm 1.19$ \\
\hline & $\begin{array}{c}1 . \overline{42} \\
(0.79-2.55)\end{array}$ & $\begin{array}{c}1 . \overline{70} \\
(0.96-3.02)\end{array}$ & $\begin{array}{c}1 . \overline{08} \\
(0.55-210)\end{array}$ & $\begin{array}{c}1 . \overline{09} \\
(0.59-2.00)\end{array}$ \\
\hline \multirow[t]{3}{*}{$\operatorname{CRP}(\mathrm{mg} / \mathrm{l})^{\mathrm{b}}$} & $0.83 \pm 1.62$ & $1.05 \pm 2.17$ & $1.44 \pm 2.97$ & $1.56 \pm 1.97$ \\
\hline & $0 . \overline{37}$ & $0 . \overline{45}$ & $0 . \overline{7} 7$ & $0 . \overline{8} 7$ \\
\hline & $(0.13-1.11)$ & $(0.14-1.44)$ & $(0.29-2.06)$ & $(0.30-2.50)$ \\
\hline \multirow[t]{3}{*}{ II-6 (ng/l) ${ }^{b}$} & $1.25 \pm 1.52$ & $1.50 \pm 1.96$ & $1.54 \pm 1.83$ & $1.09 \pm 0.99$ \\
\hline & $0 . \overline{80}$ & $0 . \overline{8} 8$ & $1 . \overline{03}$ & $0 . \overline{84}$ \\
\hline & $(0.32-2.04)$ & $(0.32-2.43)$ & $(0.44-2.41)$ & $(0.41-1.71)$ \\
\hline \multirow[t]{2}{*}{ TNF- $\alpha(n g / l)^{b}$} & $2.78 \pm 3.10$ & $3.73 \pm 4.57$ & $2.19 \pm 4.43$ & $2.51 \pm 4.42$ \\
\hline & $\begin{array}{c}1.68 \\
(0.8-492)\end{array}$ & $\begin{array}{c}1.94 \\
(05-678)\end{array}$ & $\begin{array}{c}0.91 \\
(0,-311)\end{array}$ & \\
\hline \multirow{3}{*}{ AST activity $(\mathrm{U} / \mathrm{I})^{\mathrm{b}}$} & $\begin{array}{r}(0.58-4.92) \\
23.9 \pm 6.5\end{array}$ & $\begin{array}{r}(0.55-6 . / 8) \\
20.6 \pm 5.0\end{array}$ & $\begin{array}{r}(0.21-3.11) \\
25.9+8.8\end{array}$ & $\begin{array}{r}(0.25-3.84) \\
19.0 \pm 5.5\end{array}$ \\
\hline & 23.1 & 20.0 & 24.9 & 18.3 \\
\hline & $(17.9-29.9)$ & $(15.8-25.3)$ & $(18.7-33.0)$ & $(14.1-23.9)$ \\
\hline \multirow{3}{*}{ ALP activity $(\mathrm{U} / \mathrm{I})^{\mathrm{b}}$} & $187.7 \pm 102.2$ & $123.0 \pm 85.6$ & $70.1 \pm 20.3$ & $58.3 \pm 15.7$ \\
\hline & $1 \overline{16} .7$ & 101.0 & 67.5 & 56.5 \\
\hline & $(92.9-281.4)$ & $(54.9-187.8)$ & $(51.5-88.4)$ & $(43.9-72.6)$ \\
\hline \multirow[t]{3}{*}{ sICAM-1 $(\mathrm{mg} / \mathrm{l})^{\mathrm{b}}$} & $275.3 \pm 57.7$ & $267.0 \pm 58.3$ & $268.1 \pm 66.3$ & $251.9 \pm 65.4$ \\
\hline & 268.9 & 260.2 & 360.3 & 243.2 \\
\hline & $(215.4-335.9)$ & $(205.5-329.6)$ & $(203.6-332.6)$ & $(184.0-321.5)$ \\
\hline R241 allele frequency (\%) & 9.66 & 10.95 & 10.16 & 11.88 \\
\hline \multicolumn{5}{|l|}{ ICAM-1 genotype (\%) } \\
\hline G/G & 81.1 & 79.1 & 81.9 & 76.7 \\
\hline $\mathrm{G} / \mathrm{R}$ & 18.4 & 19.9 & 15.9 & 22.7 \\
\hline$R / R$ & 0.5 & 1.0 & 2.2 & 0.6 \\
\hline
\end{tabular}

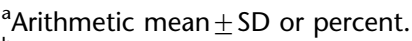

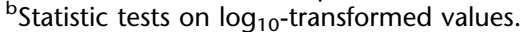

${ }^{\mathrm{C}}$ Geometric means.

dRange of $1 \mathrm{SD}$.

${ }^{\mathrm{e}} \mathrm{HOMA}=($ fasting insulin $(\mathrm{mlU} / \mathrm{l}) *$ fasting glucose $(\mathrm{mmol} / \mathrm{l})) / 22.5$.

separately in children (6-21 years) and adults (38-55 years). ICAM-1 R241 genotype was tested in autosomal dominant (GG vs GR+RR), codominant (GG vs GR vs RR), recessive (GG + GR vs RR) and allelic dose effect models. In addition, interaction terms between ICAM-1 polymorphism (as dominant score: GG $v s \mathrm{GR}+\mathrm{RR}$ ) and age (as 
continuous variable), male sex and current smoking (as categorical variable) were tested in the model. $P \leqslant 0.05$ was regarded as statistically significant.

For both children and adult groups, the best model for age- and sex-adjusted sICAM-1 level was summarized by multiple linear regression with ICAM-1 polymorphism and the covariates significantly associated at least in one group. As individuals within a family were not independent, ANOVA and final multiple linear regression analysis were conducted by using the SAS GENMOD procedure with a family factor as repeated statement. GENMOD was based on the generalized estimating equation (GEE). GEE provides a practical method with reasonable statistical efficiency to analyze correlated data such as familial data by modelling the covariance structure of the correlated measurements. Unlike other methods, the measurements must not be assumed to be multivariate normal. ${ }^{30}$

\section{Results}

\section{Baseline characteristics}

Baseline characteristics of the population are given in Table 1. The means \pm SD for age were $15.4 \pm 3.3,15.4 \pm 3.0$, $44.7 \pm 3.9$ and $43.1 \pm 4.1$ years for boys, girls, men and women, respectively. Mean values or frequencies for BMI, blood pressure, alcohol, tobacco and drug intake, and all biological constituents (leukocyte and platelet count, triglycerides, total cholesterol, apoA-I, apoB, glucose, insulin, HOMA index, CRP, Il-6, TNF- $\alpha$, AST, ALP) were in accordance with the values found in apparently healthy individuals of the same age and sex. Mean levels of sICAM1 were significantly different between the four groups $(P \leq 0.001)$.

Allelic frequencies of the ICAM-1 polymorphism were in Hardy-Weinberg equilibrium in children and adults. The R241 allelic frequencies were 9.7, 10.9, 10.2 and 11.9\% for boys, girls, men and women, respectively.

\section{Effects of age and sex on sICAM-1 level}

Figure 1 shows geometric means for serum sICAM-1 level according to sex and age (6-11, 12-14, 15-17 and 18-21 years for children; $38-42,43-47$ and 48-55 years for adults). From 6 to 21 years, sICAM-1 levels significantly decreased for both boys and girls (global ANOVA, $P \leqslant 0.001$ ) and the levels did not differ between the sexes. According to the multiple comparison test, sICAM-1 concentrations did not significantly differ between 15 and 21 years for both boys and girls, and the average level for the three age groups (6-11, 12-14 and 15-21 years) significantly differed from each other. For adults of both sexes, there was no significant difference due to the age between 38 and 55 years, while sICAM-1 levels were lower in women than in men (global ANOVA, $P \leqslant 0.01$ ), probably due to discrepancy in the older age group ( $48-55$ years). However, the multiple comparison test showed that sICAM-1 levels

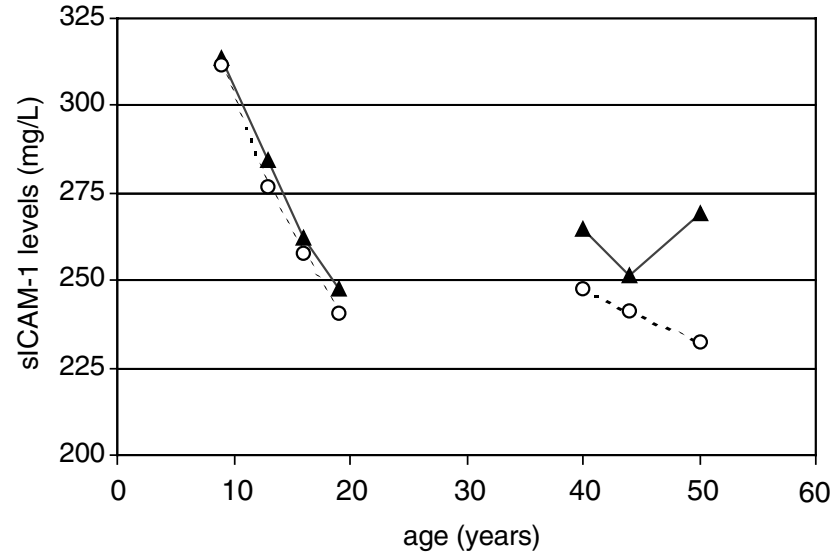

Figure 1 Geometric means of serum sICAM-1 concentration according to age and sex: $(\boldsymbol{\Lambda})$ male and $(\bigcirc)$ female.

did not significantly differ between sexes within each age group (38-42, 43-47 and 48-55 years).

\section{Determinants of serum sICAM-1 level}

In multiple regression analysis (Table 2), ICAM-1 R241 polymorphism was associated with sICAM-1 levels after adjustment for age, sex, smoking status, Il-6, AST, ALP and HOMA index. Among the four tested patterns (dominant (GG vs GR + RR), codominant (GG vs GR vs RR), recessive $(\mathrm{GG}+\mathrm{GR} v s \mathrm{RR})$ and allelic ( $\mathrm{R} v \mathrm{G})$ ), the codominant pattern contributed better to the model after adjustment for covariates improvement (in children $R^{2}$ values were 0.034 vs $0.027,0.012$ and 0.031 ; in adults 0.019 vs 0.012 , 0.011 and 0.016 for codominant, dominant, recessive and allelic patterns, respectively). GR and RR genotypes were associated with lower sICAM-1 levels in both children and adults groups, the GG genotype being the reference group. As expected, the RR homozygote effect was higher than that of the GR heterozygote. Although genotype contribution was higher in children than in adults, the interaction term (product: codominant pattern * age group) was not significant in regression analysis using the overall population.

Covariates and polymorphism explained 20.1 and $26.4 \%$ of the variability of sICAM-1 in children and adults, respectively. In these two groups, Il-6 level, AST and ALP activities were positively related to sICAM-1 level. For children only, the HOMA index was positively correlated with sICAM-1 concentration, and for adults only, the sICAM-1 level was higher among heavy smokers. Tests for interactions between polymorphism and age, sex or smoking status were not significant (data not shown).

\section{Discussion}

The present study is the first evidence for an association between G/R241 ICAM-1 gene polymorphism and serum 
Table 2 Predictors of serum sICAM-1 concentrations in children and adults by multiple regression analysis adjusted for sex and age ${ }^{a, b}$

\begin{tabular}{|c|c|c|}
\hline & Children & Adults \\
\hline \multicolumn{3}{|l|}{ ICAM-1 R241 genotype } \\
\hline $\begin{array}{l}\mathrm{G} / \mathrm{R} \text { vs } \mathrm{G} / \mathrm{G} \\
\mathrm{R} / \mathrm{R} \text { vs } \mathrm{G} / \mathrm{G}\end{array}$ & $\begin{array}{l}-0.038(0.011)^{* * *} \\
-0.145(0.039)^{\star * *}\end{array}$ & $\begin{array}{l}-0.025(0.012)^{*} \\
-0.112(0.053)^{*}\end{array}$ \\
\hline \multicolumn{3}{|l|}{ Current smoking } \\
\hline$\leq 10 \mathrm{cig} /$ day vs nonsmokers & $-0.003(0.023)$ & $0.025(0.018)$ \\
\hline$>10$ cig/day vs nonsmokers & $0.053(0.031)$ & $0.119(0.018)^{\star * \star}$ \\
\hline HOMA IR index & $0.050(0.018)^{\star \star}$ & $-0.013(0.037)$ \\
\hline II-6 (ng/l) & $0.025(0.013)^{*}$ & $0.037(0.016)^{*}$ \\
\hline ALP activity $(U / I)^{b}$ & $0.063(0.032)^{\star}$ & $0.178(0.048)^{\star * *}$ \\
\hline AST activity $\left(\mathrm{U} / \mathrm{I}^{\mathrm{b}}\right.$ & $0.169(0.049)^{\star \star *}$ & $0.164(0.048)^{\star * \star}$ \\
\hline Intercept & 2.045 & 1.836 \\
\hline$R^{2}$ & 0.201 & 0.264 \\
\hline
\end{tabular}

${ }^{\text {a }}$ Regression coefficient (SE); ${ }^{*} P \leqslant 0.05,{ }^{* *} P \leqslant 0.01,{ }^{* \star *} P \leqslant 0.001$.

${ }^{\mathrm{b}} \mathrm{Log}_{10}$-transformed values.

sICAM-1 concentration. We found that the R241 allele was associated with lower sICAM-1 level independently of other factors influencing sICAM-1 concentration (smoking status, HOMA index, Il-6 concentration, and AST and ALP activities) in a codominant genetic model. To date, only in one study the relation between the G/R241 mutation and sICAM-1 level in a healthy sample of 44 Palestinians and Jordanians was investigated, but the authors ${ }^{23}$ failed to find a significant association probably due to lack of power and very low R241 allelic frequency (about 1.5\%).

sICAM-1 mean concentrations and variability observed in the present study are similar to those reported in other healthy populations (using the commercial ELISA kit from R\&D System). ${ }^{31-36}$ Regarding G/R241 ICAM-1 polymorphism, there is a heterogeneity in the genotype distribution in healthy populations across the world with ethnic differences in R241 allele frequency. ${ }^{20}$ In particular, across Europe, R241 allele frequency was higher in the north compared with the south: $18 \%$ in Poland; ${ }^{17} 14.3 \%$ in Estonia; $^{18} 11.4 \%$ in Germany; ${ }^{25} 9.4 \%$ in the $\mathrm{UK}^{37} 8.1 \%$ in Northwest Spain; ${ }^{22}$ 5.7, 4.0 and 3.1\% in Italy. ${ }^{13,24,15}$ Values of R241 allele frequency (9.7-11.9\%) obtained in our sample population from the north-east of France are consistent with this north-south gradient.

The G/R241 mutation results in a change from glycine to arginine in the third immunoglobulin domain of ICAM-1 protein, ${ }^{10}$ which has been shown to be of importance in binding to the leukocyte integrin Mac- $1 .^{38}$ The common allele is G241, and glycine is present at the analogous position in ICAM-1 from other species. ${ }^{39-41}$ Owing to the strong conservation of glycine at position 241, this mutation may possess a functional significance, probably by affecting Mac-1 binding. Otherwise, membrane-bound ICAM-1 acts as a signal transduction molecule in response to ligand binding with resulting activation of second messenger systems and gene transcription. ${ }^{42}$ In this way, crosslinking ICAM-1 on primary human fibroblasts with
anti-ICAM-1 antibody elicited a significant increase in ICAM-1 mRNA and protein expression. ${ }^{43}$ Engagement of ICAM-1 triggers the stimulation of de novo ICAM-1 synthesis. Accordingly, we speculate that an R241 mutation decreases Mac-1 binding to ICAM-1 and thus reduces its positive feedback on ICAM-1 synthesis, which could explain the lower sICAM-1 level associated with the R241 allele.

We cannot exclude, however, the possibility that the effect of R241 mutation on sICAM-1 level may be due to linkage disequilibrium of this mutation with other genetic polymorphisms affecting sICAM-1 level. Only the K/E469 polymorphism of ICAM-1 gene was observed in linkage disequilibrium with the G/R241 mutation in patients affected by inflammatory disorders. ${ }^{20}$ However, the association of K/E469 mutation with the protein level has never been studied and we cannot exclude that the effect of R241 allele on sICAM-1 level could be influenced by the K/E469 polymorphism.

The association between the R241 allele and low sICAM1 level observed in this study could seem to contradict the reported associations between the R241 allele and inflammatory disorders, ${ }^{11-15}$ and the increased sICAM-1 level at the related inflammation disorders. ${ }^{4,8,26}$ The phenotypegenotype association described in our study was observed in a healthy population, and this relation cannot be excluded to remain significant in pathological states. The strong increase of sICAM-1 level due to inflammatory diseases could certainly hide the significant but weak decrease of sICAM-1 level associated with the R241 allele. Thus, additional studies are warranted to investigate the association between the R241 allele with sICAM-1 level in pathological state. Moreover, there is no general consensus about the relation between G/R241 polymorphism and inflammation. While some studies reported association between the R241 allele and inflammatory disorders, ${ }^{11-15}$ others did not. ${ }^{16-24}$ These conflicting results may be 
explained by the small size of the case-control groups, the heterogeneity of diseases and the ethnic background variety of different populations. Thus, the lower sICAM-1 level associated with R241 allele in this study is common in the physiological state, but cannot be extended for the pathological state.

In addition to the G/R241 polymorphism, sICAM-1 level was influenced by various biological factors such as age, sex, smoking, insulin resistance, Il-6 level, and ALP and AST activities. Levels of sICAM-1 decreased during childhood and adolescence and varied very slightly between 38 and 55 years. The inverse relation between age and sICAM1 level has been previously reported at childhood, ${ }^{44-47}$ but its physiological significance is currently unknown. At healthy adulthood, the stability of sICAM- 1 level across age is well known. ${ }^{31,32,34,48}$

In our study, men had a slightly higher sICAM-1 level than women, probably due to the discrepancy in the older age group (48-55 years). The variation of sICAM-1 level according to sex has not been established yet. However, sex difference could be due to hormonal effect: adhesion molecule expression decreased after estrogen treatment in in vitro studies ${ }^{49,50}$ and sICAM-1 level decreased in postmenopausal women under hormone therapy. ${ }^{51-54}$

Heavy smoking increased sICAM-1 level in the adults in our study in accordance with others; ${ }^{31,33,55-59}$ tobacco stimulates endothelial cells through proinflammatory pathways in in vitro studies. ${ }^{60,61}$

Our study shows that the insulin resistance index was positively related to sICAM-1 but only for children. An increased sICAM-1 level with increasing insulin resistance has been described already, but only for healthy adults. ${ }^{62}$ It is possible that this association was only due to the higher HOMA index in children than in adults. ${ }^{63}$

Il-6, a proinflammatory cytokine, was positively associated with sICAM-1 level without significant association with the other inflammatory markers (CRP and TNF- $\alpha$ ). In this way, in vivo studies have shown that Il-6 induced ICAM-1 expression. ${ }^{35,36}$

The sICAM-1 level was positively related to AST and ALP activities. Since the subjects were free of hepatic diseases and bone disorders, and inflammatory markers were included in the statistic regression model, these associations did not seem to be due to pathological status. To our knowledge, there is no information that could explain the biological basis of such relations with AST and ALP activities in the physiological state.

To summarize, the R241 allele of ICAM-1 gene is associated with lower serum sICAM-1 level in healthy subjects. This association is unaffected by parameters that influence sICAM-1 level, particularly age, sex and tobacco intake. This result outlines the impact of ICAM-1 gene polymorphism on protein expression; further studies are needed, however, to confirm the functional significance of the G/R241 mutation.

\section{Acknowledgements}

We are grateful to Professor G Siest and Dr C Sass for their close involvement in the management of the Stanislas cohort. We are also indebted to the staff of the Centre de Médecine Préventive of Vandoeuvre-lès-Nancy, France, and the participants of the Stanislas cohort, who made this study possible. We thank $N$ Haddy for providing the Il-6 and TNF- $\alpha$ measurements. The Stanislas cohort study is supported by the Caisse Nationale d'Assurance Maladie des Travailleurs Salariés (CNAM), the Institut National de Santé et de Recherche Médicale (INSERM), the Région Lorraine, the Communauté Urbaine de Nancy, the Université Henri Poincaré Nancy I, Bayer-Pharma, Hoffmann-LaRoche, Beckmann-Coulter, Biomérieux, Daiichi Pure Chemicals, Randox, Dade-Behring. This study was supported by an IDS grant (INSERM No. 4DOOSE/1999). We are particularly grateful to Roche Molecular Systems for providing us with materials to perform ICAM-1 genotyping.

\section{References}

1 Springer TA: Traffic signals on endothelium for lymphocyte recirculation and leukocyte emigration. Annu Rev Physiol 1995; 57: $827-872$.

2 Budnik A, Grewe M, Gyufko K, Krutmann J: Analysis of the production of soluble ICAM-1 molecules by human cells. Exp Hematol 1996; 24: 352-359.

3 Rothlein R, Mainolfi EA, Czajkowski M, Marlin SD: A form of circulating ICAM-1 in human serum. I Immunol 1991; 147: $3788-3793$

4 Sfikakis PP, Tsokos GC: Clinical use of the measurement of soluble cell adhesion molecules in patients with autoimmune rheumatic diseases. Clin Diagn Lab Immunol 1997; 4: 241-246.

5 Kelly KA: Modulation of leukocyte-endothelial cell interactions by infectious agents. Bull Inst Pasteur 1997; 95: 147-159.

6 Labarrere CA, Nelson DR, Park JW: Pathologic markers of allograft arteriopathy: insight into the pathophysiology of cardiac allograft chronic rejection. Curr Opin Cardiol 2001; 16: 110-117.

7 Banks RE, Gearing AJ, Hemingway IK, Norfolk DR, Perren TJ, Selby PJ: Circulating intercellular adhesion molecule-1 (ICAM-1), E-selectin and vascular cell adhesion molecule-1 (VCAM-1) in human malignancies. Br J Cancer 1993; 68: 122-124.

8 Eppihimer MJ: The role of leukocyte-endothelial cell adhesion in cardiovascular disease. Pathophysiology 1998; 5: 167-184.

9 Vora DK, Rosenbloom CL, Beaudet AL, Cottingham RW: Polymorphisms and linkage analysis for ICAM-1 and the selectin gene cluster. Genomics 1994; 21: 473-477.

10 Staunton DE, Marlin SD, Stratowa C, Dustin ML, Springer TA: Primary structure of ICAM-1 demonstrates interaction between members of the immunoglobulin and integrin supergene families. Cell 1988; 52: 925-933.

11 Braun C, Zahn R, Martin K, Albert E, Folwaczny C: Polymorphisms of the ICAM-1 gene are associated with inflammatory bowel disease, regardeless of the p-ANCA status. Clin Immunol 2001; 101: 357-360.

12 Yang H: Analysis of ICAM-1 gene polymorphism in immunologic subsets of inflammatory bowel disease. Exp Clin Immunogenet 1997; 14: 214-225.

13 Macchioni P, Boiardi L, Casali B, Nicoli D, Farnetti E, Salvarani C: Intercellular adhesion molecule 1 (ICAM-1) gene polymorphisms in Italian patients with rheumatoid arthritis. Clin Exp Rheumatol 2000; 18: 553-558.

14 Salvarani C, Casali B, Boiardi L et al: Intercellular adhesion molecule 1 gene polymorphisms in polymyalgia rheumatica/ giant cell arteritis: association with disease risk and severity. J Rheumatol 2000; 27: 1215-1221.

15 Boiardi L, Salvarani C, Casali B et al: Intercellular adhesion molecule-1 gene polymorphisms in Behcet's Disease. J Rheumatol 2001; 28: $1283-1287$. 
16 Amoli MM, Shelley E, Mattey DL et al: Lack of association between intercellular adhesion molecule-1 gene polymorphisms and giant cell arteritis. J Rheumatol 2001; 28: 1600-1604.

17 Mycko MP, Kwinkowski M, Tronczynska E, Szymanska B, Selmaj KW: Multiple sclerosis: the increased frequency of the ICAM-1 exon 6 gene point mutation genetic type K469. Ann Neurol 1998; 44: $70-75$.

18 Hirv K, Seyfarth M, Uibo R et al: Polymorphisms in tumour necrosis factor and adhesion molecule genes in patients with inflammatory bowel disease: associations with HLA-DR and -DQ alleles and subclinical markers. Scand J Gastroenterol 1999; 34: $1025-1032$.

19 Amoli MM, Shelley E, Mattey Dl et al: Intercellular adhesion molecule-1 gene polymorphisms in isolated polymyalgia rheumatica. J Rheumatol 2002; 29: 502-504.

20 Yang $\mathrm{H}$, Vora DK, Targan SR, Toyoda $\mathrm{H}$, Beaudet Al, Rotter JI: Intercellular adhesion molecule 1 gene associations with immunologic subsets of inflammatory bowel disease. Gastroenterology 1995; 109: 440-448.

21 Yang H: Analysis of ICAM-1 gene polymorphism in immunologic subsets of inflammatory bowel disease. Exp Clin Immunogenet 1997; 14: 241-225.

22 Amoli MM, Mattey DL, Calvino MC et al: Polymorphism at codon 469 of the intercellular adhesion molecule-1 locus is associated with protection against severe gastrointestinal complications in Henoch-Schonlein purpura. J Rheumatol 2001; 28: 1014-1018.

23 Verity DH, Vaughan RW, Kondeatis E et al: Intercellular adhesion molecule-1 gene polymorphisms in Behcet's disease. Eur J Immunogenet 2000; 27: 73-76.

24 Marrosu MG, Schirru L, Fadda E et al: ICAM-1 gene is not associated with multiple sclerosis in sardinian patients. J Neurol 2000; 247: 677-680.

25 Wenzel K, Ernst M, Rohde K, Baumann G, Speer A: DNA polymorphisms in adhesion molecule genes-a new risk factor for early atherosclerosis. Hum Genet 1996; 97: 15-20.

26 Gomez-Scotto E, Seigneur M, Renard M, Houbouyan-Reveillard LL, Boisseau MR: Interest in variations in soluble ICAM-1 plasma levels. From physiology to clinical application. J Mal Vasc 2000; 25: $156-165$.

27 Siest G, Visvikis S, Herbeth B et al: Objectives, design and recruitment of a familial and longitudinal cohort for studying gene-environment interactions in the field of cardiovascular risk: the Stanislas cohort. Clin Chem Lab Med 1998; 36: 35-42.

28 Miller SA, Dykes DD, Polesky HF: A simple salting out procedure for extracting DNA from human nucleated cells. Nucleic Acids Res 1988; 16: 1215.

29 Cheng S, Pallaud C, Grow MA et al: A multilocus genotyping assay for cardiovascular disease. Clin Chem Lab Med 1998; 36: $561-566$

30 Hanley JA, Negassa A, Edwardes MD, Forrester JE: Statistical analysis of correlated data using generalized estimating equations: an orientation. Am J Epidemiol 2003; 157: 364-375.

31 Demerath E, Towne B, Blangero J, Siervogel RM: The relationship of soluble ICAM-1, VCAM-1, P-selectin and E-selectin to cardiovascular disease risk factors in healthy men and women. Ann Hum Biol 2001; 28: 664-678.

32 Rohde LE, Lee RT, Rivero J et al: Circulating cell adhesion molecules are correlated with ultrasound-based assessment of carotid atherosclerosis. Arterioscler Thromb Vasc Biol 1998; 18: $1765-1770$.

33 Rohde LE, Hennekens CH, Ridker PM: Cross-sectional study of soluble intercellular adhesion molecule- 1 and cardiovascular risk factors in apparently healthy men. Arterioscler Thromb Vasc Biol 1999; 19: 1595-1599.

34 Hwang SJ, Ballantyne CM, Sharrett AR et al: Circulating adhesion molecules VCAM-1, ICAM-1, and E-selectin in carotid atherosclerosis and incident coronary heart disease cases: the Atherosclerosis Risk In Communities (ARIC) study. Circulation 1997; 96: 4219-4225.
35 Waron C, Whittaker S, Smith N, Vora AJ, Brown KA: Il-6 acts on endothelial cells to preferentially increase their adherence for lymphocytes. Clin Exp Immunol 1996; 105: 112-119.

36 Romano M, Sironi M, Toniatti C et al: Role of Il-6 and its soluble receptor in induction of chemokines and leukocyte recruitment. Immunity 1997; 6: 315-325.

37 McLaren AJ, Marshall SE, Haldar NA et al: Adhesion molecule polymorphisms in chronic renal allograft failure. Kidney Int 1999; 55: $1977-1982$.

38 Diamond MS, Staunton DE, Marlin SD, Springer TA: Binding of the integrin Mac-1 (CD11b/CD18) to the third immunoglobulinlike domain of ICAM-1 (CD54) and its regulation by glycosylation. Cell 1991; 65: 961-971.

39 Smith CW, Entman ML, Lane CL et al: Adherence of neutrophils to canine cardiac myocytes in vitro is dependent on intercellular adhesion molecule-1. J Clin Invest 1991; 88: 1216-1223.

40 Ballantyne CM, Kozak CA, O'Brien WE, Beaudet AL: Assignment of the gene for intercellular adhesion molecule-1 (Icam-1) to proximal mouse chromosome 9. Genomics 1991; 9: 547-550.

41 Kita Y, Takashi T, Iigo Y, Tamatani T, Miyasaka M, Horiuchi T: Sequence and expression of rat ICAM-1. Biochim Biophys Acta 1992; 1131: $108-110$.

42 Hubbard AK, Rothlein R: Intercellular adhesion molecule-1 (ICAM-1) expression and cell signaling cascades. Free Radic Biol Med 2000; 28: 1379-1386.

43 Clayton A, Evans RA, Pettit E, Hallett M, Williams JD, Steadman $\mathrm{R}$ : Cellular activation through the ligation of intercellular adhesion molecule-1. J Cell Sci 1998; 111: 443-453.

44 Nash MC, Wade AM, Shah V, Dillon MJ: Normal levels of soluble E-selectin, soluble intercellular adhesion molecule-1 (sICAM-1), and soluble vascular cell adhesion molecule-1 (sVCAM-1) decrease with age. Clin Exp Immunol 1996; 103: 167-170.

45 Andrys C, Pozler O, Krejsek J, Derner V, Drahosova M, Kopecky O: Serum soluble adhesion molecules (sICAM-1, sVCAM-1 and sEselectin) in healthy school aged children and adults. Acta Med 2000; 43: 103-106.

46 Sack U, Burkhardt U, Borte M, Schadlich H, Berg K, Emmrich F: Age-dependent levels of select immunological mediators in sera of healthy children. Clin Diagn Lab Immunol 1998; 5: 28-32.

47 Ohta T, Saku K, Takata K, Adachi N: Soluble vascular celladhesion molecule-1 and soluble intercellular adhesion molecule-1 correlate with lipid and apolipoprotein risk factors for coronary artery disease in children. Eur J Pediatr 1999; 158: $592-598$.

48 Blann AD, Daly RJ, Amiral J: The influence of age, gender and $\mathrm{ABO}$ blood group on soluble endothelial cell markers and adhesion molecules. Br J Haematol 1996; 92: 498-500.

49 Seeger H, Wallwiener D, Mueck AO: Lipid-independent effects of an estrogen-statin combination: inhibition of expression of adhesion molecules and plasminogen activator inhibitor-I in human endothelial cell cultures. Climacteric 2001; 4: 209-214.

50 Caulin-Glaser T, Watson CA, Pardi R, Bender JR: Effects of 17betaestradiol on cytokine-induced endothelial cell adhesion molecule expression. J Clin Invest 1996; 98: 36-42.

51 Oger E, Alhenc-Gelas M, Plu-Bureau G et al: Association of circulating cellular adhesion molecules with menopausal status and hormone replacement therapy. Time-dependent change in transdermal, but not oral estrogen users. Thromb Res 2001; 101: $35-43$

52 Koh KK, Jin DK, Yang SH et al: Vascular effects of synthetic or natural progestagen combined with conjugated equine estrogen in healthy postmenopausal women. Circulation 2001; 103: $1961-1966$

53 Zanger D, Yang BK, Ardans J et al: Divergent effects of hormone therapy on serum markers of inflammation in postmenopausal women with coronary artery disease on appropriate medical management. J Am Coll Cardiol. 2000; 36: 1797-1802.

54 Guzic-Salobir B, Keber I, Seljeflot I, Arnesen H, Vrabic L: Combined hormone replacement therapy improves endothelial 
function in healthy postmenopausal women. J Intern Med 2001; 250: $508-515$.

55 Koundouros E, Odell E, Coward P, Wilson R, Palmer RM: Soluble adhesion molecules in serum of smokers and nonsmokers, with and without periodontitis. J Periodontal Res 1996; 31: 596-599.

56 Blann AD, Steele C, McCollum CN: The influence of smoking on soluble adhesion molecules and endothelial cell markers. Thromb Res 1997; 85: 433-438.

57 Bergmann S, Siekmeier R, Mis C, Jaross W: Even moderate cigarette smoking influences the pattern of circulating monocytes and the concentration of sICAM-1. Respir Physiol 1998; 114: 269-275.

58 Bermudez EA, Rifai N, Buring JE, Manson JE, Ridker PM: Relation between markers of systemic vascular inflammation and smoking in women. Am J Cardiol 2002; 89: 1117-1119.

59 Ridker PM, Hennekens CH, Roitman-Johnson B, Stampfer MJ, Allen J: Plasma concentration of soluble intercellular adhesion molecule 1 and risks of future myocardial infarction in apparently healthy men. Lancet 1998; 351: 88-92.

60 Shen Y, Rattan V, Sultana C, Kalra VK: Cigarette smoke condensate-induced adhesion molecule expression and transendothelial migration of monocytes. Am J Physiol 1996; 270: H1624-H1633.

61 Furie MB, Raffanello JA, Gergel EI, Lisinski TJ, Horb LD: Extracts of smokeless tobacco induce pro-inflammatory changes in cultured human vascular endothelial cells. Immunopharmacology 2000; 47: 13-23.

62 Chen N-G, Holmes M, Reaven GM: Relationship between insulin resistance, soluble adhesion molecules and mononuclear cell binding in healthy volunteers. J Clin Metab Endocrinol 1999; 84: $3485-3489$

63 Hrebicek J, Janout V, Malincikova J, Horakova D, Cizek L: Detection of insulin resistance by simple quantitative insulin sensitivity check index QUICKI for epidemiological assessment and prevention. J Clin Metab Endocrinol 2002; 87: 144-147. 